\title{
Experimental Investigation of an Automotive Air Conditioning System Using R444A and R152a Refrigerants as Alternatives of R134a
}

\author{
Mehmet Direk* - Mehmet Selçuk Mert - Eren Soylu - Fikret Yüksel \\ Yalova University, Faculty of Engineering, Turkey
}

\begin{abstract}
The conventional refrigerants used in refrigeration systems cause global warming effect if released into the atmosphere. To overcome this problem, refrigerants are classified according to their global warming potential (GWP) values, and some restrictions have been placed on the use and transport of these refrigerants with European regulations. Vapor compression refrigeration (VCR) systems are used to provide desired conditions in many systems and as well as in automobiles. Most of the automotive air conditioning (AAC) systems use R134a which has GWP value of 1300. In this study, the use of the refrigerants which have low GWP values, namely, R152a and R444A as an alternative to the R134a for AAC systems, were investigated experimentally. Moreover, the effect of a plate-type internal heat exchanger (IHX) added into the system was studied with the refrigerant R444A. The cooling capacity, compressor power, coefficient of performance (COP) and total exergy destruction have been determined as performance parameters. Based on the obtained results, the highest COP and cooling capacity were achieved when the R152a used as the refrigerant. Furthermore, the COP of the system was increased when the IHX was used, with R444A as the refrigerant.
\end{abstract}

Keywords: R134a, R152a and R444A, automotive air conditioning, coefficient of performance

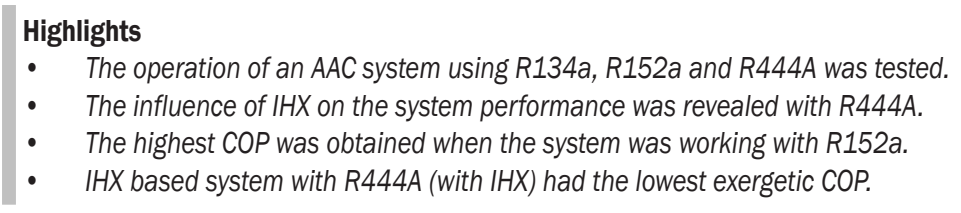

\section{INTRODUCTION}

The European Union brings some restrictions to the use of some refrigerants, which has been higher than 150 global warming potential (GWP) value, in mobile air conditioning (MAC) systems as in directive no 2006/40/EC [1]. Then these GWP limits were extended air conditioning and refrigeration systems with regulation the Regulation (EU) No, 517/2014 [2].

Presently, most of the MAC systems use R134a as the refrigerant; however, the GWP value of the R134a is 1300 [3] and [4]. The refrigerants such as R1234yf, R1234ze(E), R152a and R444A, can be considered as alternative refrigerants having low GWP for automotive air conditioning systems. Table 1 shows the thermophysical properties of the above-mentioned refrigerants. Among them, R1234ze(E) can be used instead of R134a due to the their similar properties [5].

However, the cooling performance of R1234ze(E) is $30 \%$ lower in average than that of R134a when used in a similar medium capacity vapor compression system [6] to [8]. Furthermore, the performance of R1234ze(E) can be improved when the mixture of some refrigerants used to obtain required properties. The R444A consists of $83 \%$ R1234ze(E), $12 \%$ R32 and $5 \%$ R152a, (by mass) and its GWP value is 93 [4] and [9] which meets the European regulations.

Devecioğlu and Oruç [10] calculated the performance parameters of R1234yf, R444A and R445A for a MAC system. It was found that the R444A and R445A have lower cooling capacity, but higher coefficient of performance (COP) than that of R1234yf. Lee et al. [11] investigated the performance of R444A, R445A, R152a, and R1234yf in an automotive air conditioning (AAC) system as an alternative to R134a. The highest COP was obtained when the system was working with R152a. Cheng et al. [9] tested an air source heat pump (HP) system using the different concentrations of R32/R1234ze(E) mixture numerically.

It was determined that the heating and cooling capacities were improved compared to the R134a baseline system. Meng et al. [12] determined the performance of a refrigeration system using the mixture of R152a and R1234ze(E) refrigerants as an alternative to R134a. The mixture of $50 \% \mathrm{R} 1234 \mathrm{ze}(\mathrm{E})$ and $50 \%$ R152a was found to be the best alternative for R134a. It was demonstrated that the cooling capacity of $\mathrm{R} 1234 \mathrm{ze}(\mathrm{E}) / \mathrm{R} 152 \mathrm{a}$ mixture was very similar to R134a and can be used without any change in the compressor. Li et al. [13] reported that R134a 
Table 1. Refrigerant properties of R134a, R152a, R444A, R1234ze(E), R1234yf [3]

\begin{tabular}{lccccc}
\hline Property & R134a & R152a & R444A & R1234ze(E) & R1234yf \\
\hline ASHRAE safety classification & A1 & A2 & A2L & A2L & A2L \\
\hline Ozone depletion potential (ODP) & 0 & 0 & 0 & 0 & 0 \\
\hline GWP $[4]$ & 1300 & 124 & 93 & 4 & 4 \\
\hline Critical temperature [ $\left.{ }^{\circ} \mathrm{K}\right]$ & 374.21 & 386.41 & 374.39 & 382.51 & 367.85 \\
\hline Critical pressure $[\mathrm{kPa}]$ & 4059.3 & 4516.8 & 4235.8 & 3634.9 & 3382.2 \\
\hline Vapor density $\left[\mathrm{kg} \cdot \mathrm{m}^{-3}\right]\left(\right.$ at $\left.0{ }^{\circ} \mathrm{C}\right)$ & 32.35 & 18.47 & 28.5 & 26.32 & 37.92 \\
\hline Liquid density $\left[\mathrm{kg} \cdot \mathrm{m}^{-3}\right]\left(\right.$ at $\left.0^{\circ} \mathrm{C}\right)$ & 1294.8 & 959.11 & 1199.1 & 1240.1 & 1176.3 \\
\hline Latent heat of vaporization $\left[\mathrm{kJ}^{\mathrm{kg}}{ }^{-1}\right]($ at $100 \mathrm{kPa})$ & 177.78 & 279.36 & 180.5 & 166.92 & 145.37 \\
\hline
\end{tabular}

and R152a work at similar pressure ranges because of the close boiling points (R134a $-26.09{ }^{\circ} \mathrm{C}$ and R152a $-24.05{ }^{\circ} \mathrm{C}$ ). R152a has $55 \%$ higher latent heat value and $40 \%$ lower liquid density when compared with R134a. Ghodbane [14] tested R152a in an AAC system as an alternative to the R134a and achieved a $15 \%$ higher COP. In another study, Scherer et al. [15] tested an HP system in which R134a and R152a were used as refrigerants and obtained similar results. Lee [16] tested an HP system which was using R134a for zero emission vehicles. The results demonstrated that when the temperature was $-10{ }^{\circ} \mathrm{C}$, the heating capacity was insufficient for cabin heating.

The performance of a vapor compression refrigeration (VCR) system can be increased by installing an internal heat exchanger (IHX) into the liquid and gas suction line. The IHX increases subcooling degree so that the enthalpy difference in the evaporator is increased and the cooling capacity is increased as well [17]. Molés et al. [18] evaluated the performance of a refrigeration system using R1234ze(E) and R1234yf as an alternative of R134a and found that the cooling capacity increases when the IHX is activated, and the COP was found to be very close to that of R134a. Mota-Babiloni et al. [19] observed that the mass flow rate was $18 \%$ to $29 \%$ lower than that of R134a when the system was working with R1234ze(E). They also determined that R1234ze(E) can provide the same cooling capacity as $\mathrm{R} 134 \mathrm{a}$ at $43 \%$ higher compressor speeds with IHX. In another study, a VCR system using IHX with R450A as an alternative to R134a was investigated. It was found that the IHX influence positively to the COP of $\mathrm{R} 450 \mathrm{~A}$, in a closed value of R134a [20].

In this study, the low GWP refrigerants, namely, the R152a and R444A, were used as an alternative to R134a, to investigate the performance of an AAC system. An IHX was also used to examine the performance of the system, and to provide an improvement. The experimental AAC system was employed with on and off valves to activate the liquid and gas suction line of the IHX. In the first part, the R134a, R152a and R444A were tested on an AAC system designed for R134a without IHX. Additionally, the effect of the IHX on the system performance was evaluated when the R444A used as the refrigerant.

\section{THERMODYNAMIC ANALYSIS}

The general energy balance for the components in the test system can be written as in Eq. (1).

$$
\dot{Q}_{C V}-\dot{W}_{C V}=\sum \dot{m}_{i} h_{i}-\sum \dot{m}_{o} h_{o} .
$$

The compressor power and cooling capacity can be evaluated by Eqs. (2) and (3), respectively.

$$
\begin{gathered}
\dot{W}_{\text {comp }}=\dot{m}_{r}\left(h_{2}-h_{1}\right), \\
\dot{Q}_{\text {evap }}=\dot{m}_{r}\left(h_{1}-h_{4}\right) .
\end{gathered}
$$

The COP can be determined, as follow:

$$
C O P=\dot{Q}_{\text {evap }} / \dot{W}_{\text {comp }} \text {. }
$$

In thermodynamic systems, it is very critical that how much of the energy is converted. When these systems are evaluated in regarding to environmental conditions, this evaluation is expressed by the concept of exergy. The reference states were taken as $T_{0}=298.15 \mathrm{~K}$ and $P_{0}=1 \mathrm{~atm}$ for this study. General exergy destruction equation for closed control volume can be written as follows.

$$
\dot{E} x_{d}=\Sigma\left(1-\frac{T_{0}}{T}\right) \dot{Q}-\sum \dot{W}+\sum_{i} \dot{m} \psi-\sum_{o} \dot{m} \psi \text {. }
$$

The exergy destruction rate for each component namely; compressor, thermostatic expansion valve, evaporator, internal heat exchanger was evaluated, as follows: 


$$
\begin{gathered}
\dot{E} x_{d, \text { comp }}=\dot{m}_{r}\left(\psi_{1}-\psi_{2}\right)+\dot{W}_{\text {comp }}, \\
\dot{E} x_{d, T X V}=\dot{m}_{r}\left(\psi_{3}-\psi_{4}\right), \\
\dot{E} x_{d, \text { evap }}=\dot{m}_{r}\left(\psi_{1}-\psi_{4}\right)+\dot{m}_{a 1}\left(\psi_{5}-\psi_{6}\right), \\
\dot{E} x_{d, \text { cond }}=\dot{m}_{r}\left(\psi_{3}-\psi_{2}\right)+\dot{m}_{a 2}\left(\psi_{7}-\psi_{8}\right), \\
\dot{E} x_{d, I H X}=\dot{m}_{r}\left(\psi_{1 b}-\psi_{1 a}\right)+\dot{m}_{r}\left(\psi_{3 b}-\psi_{3 a}\right) .
\end{gathered}
$$

Total exergy destruction can be found from the Eq. (11).

$$
\begin{aligned}
\dot{E} x_{d, t} & =\dot{E} x_{d, \text { comp }}+\dot{E} x_{d, \text { cond }}+\dot{E} x_{d, T X V}+ \\
& +\dot{E} x_{d, \text { evap }}+\dot{E} x_{d, I H X} .
\end{aligned}
$$

The exergetic efficiency can be calculated from Eq. (12) [21].

$$
\eta_{\text {exergy }}=\frac{\dot{Q}_{\text {evap }}\left(1-\frac{T_{0}}{T_{L}}\right)+\dot{Q}_{\text {cond }}\left(1-\frac{T_{0}}{T_{H}}\right)}{\dot{m}_{\text {air }} \psi_{\text {air }, \text { inlet }}+\dot{W}_{\text {comp }}} .
$$

Exergetic COP can be determined from the following equations:

$$
\begin{gathered}
C O P_{\text {carnot }}=\frac{T_{L}}{T_{H}-T_{L}}, \\
C O P_{\text {Exergetic }}=\frac{C O P_{\text {actual }}}{C O P_{\text {reversible }}} .
\end{gathered}
$$

\section{EXPERIMENTAL SETUP}

The experimental setup of the AAC system can be seen in Fig. 1. The system also includes a platetype heat exchanger between the liquid and gas suction line. The properties of experimental system components were given in Table 2.

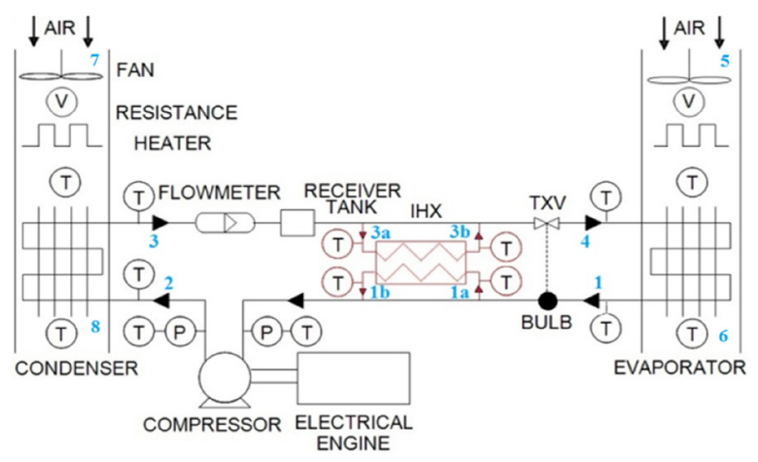

Fig. 1. Diagram of the experimental system
Table 2. Specifications of components AAC system

\begin{tabular}{lc}
\hline Components & Specifications \\
\hline Compressor & $\begin{array}{c}\text { Swash-plate type } 138 \mathrm{cc} \\
\text { Number of Cylinders: } 5\end{array}$ \\
\hline Condenser & $(580 \times 350 \times 20) \mathrm{mm}^{3}$ \\
\hline Evaporator & $(220 \times 260 \times 60) \mathrm{mm}^{3}$ \\
\hline Expansion valve & TXV (Internally equalized with bulb $5.27 \mathrm{~kW})$ \\
\hline & $(192 \times 73 \times 63) \mathrm{mm}^{3}$ \\
Internal & Type: Brazed plate \\
heat exchanger & Number of plates:24 \\
& Heat transfer area: $0.6 \mathrm{~m}^{2}$ \\
\hline
\end{tabular}

In order to provide the desired air flow temperatures in the evaporator and condenser ducts, electric heaters were used. Additionally, to provide the required air stream at the evaporator and condenser ducts, axial fans were installed.

\subsection{Test Conditions}

The AAC system was first charged with R134a. The charge amount of R134a was adjusted based on the best COP value of the system. To obtain mass equivalence between the refrigerants, the charge amount of the R152a and R444A was determined by considering liquid density (Table 1) of the R134a. The charge amount of the R134a, R152a and R444A were $625 \mathrm{~g}, 460 \mathrm{~g}$ and $512 \mathrm{~g}$, respectively. First, experiments were conducted for the system with R134a. Then the similar experiments were conducted for R152a, R444A and R444A+IHX under the same conditions. Before operating the system with different refrigerants, the system was pumped down. Then, the system was loaded with the regarded refrigerant. Finally, the steady-state conditions of the system were prepared within 10 to 15 minutes. The same amount of Polyolester (POE) oil was charged in the compressor as the lubricant during the experiments. The equipment of the AAC system was fully insulated against external influences. The measuring devices were mounted, and a data acquisition system was used for transferring the measured data. Table 3 demonstrates the properties and precisions of the measuring devices. The uncertainty values for the $\dot{Q}_{\text {evap }}, C O P, \dot{W}_{\text {comp }}, \dot{E} x_{\mathrm{d}}$, $\eta_{\text {ex }}, C O P_{\text {exergetic }}$ were calculated as $\pm 2.89 \%, \pm 3.32 \%$, $\pm 4.42 \%, \pm 4.42 \%, \pm 4.86 \%$ and $\pm 4.42 \%$, respectively.

During operation of the system, the air stream temperatures at the evaporator and the condenser duct was kept at $27{ }^{\circ} \mathrm{C}$ and $35{ }^{\circ} \mathrm{C}$, respectively. The compressor speed was increased from $750 \mathrm{rpm}$ to 2750 rpm with $500 \mathrm{rpm}$ intervals. Experimental data were taken after the steady-state conditions were reached. Additionally, computer software called REFPROP 
9.1 was used to calculate the specific enthalpies of refrigerants at given states [3].

Table 3. Specifications of the instrumentation

\begin{tabular}{llcc}
\hline Measurement & Device & \multicolumn{1}{c}{ Range } & Precision \\
\hline Temperature & $\begin{array}{l}\text { K-type } \\
\text { thermocouple }\end{array}$ & $100{ }^{\circ} \mathrm{C}$ to $1370{ }^{\circ} \mathrm{C}$ & $\pm 0.8{ }^{\circ} \mathrm{C}$ \\
\hline Pressure & $\begin{array}{l}\text { Electronic } \\
\text { manifold }\end{array}$ & $1 \mathrm{bar}$ to $60 \mathrm{bar}$ & $\pm 0.5 \%$ \\
\hline Air flow rate & Anemometer & $0 \mathrm{~m} \cdot \mathrm{s}^{-1}$ to $30 \mathrm{~m} \cdot \mathrm{s}^{-1}$ & $\pm 2 \%$ \\
\hline $\begin{array}{l}\text { Refrigerant mass } \\
\text { flow rate }\end{array}$ & $\begin{array}{l}\text { Coriolis mass } \\
\text { flow meter }\end{array}$ & $0 \mathrm{~kg} \cdot \mathrm{s}^{-1}$ to $5 \mathrm{~kg} \cdot \mathrm{s}^{-1}$ & $\pm 0.1 \%$ \\
\hline Power & Clamp meter & $0 \mathrm{~kW}$ to $600 \mathrm{~kW}$ & $\pm 2 \%$ \\
\hline $\begin{array}{l}\text { Compressor } \\
\text { speed }\end{array}$ & $\begin{array}{l}\text { Frequency } \\
\text { inverter }\end{array}$ & $10 \mathrm{~Hz}$ to $50 \mathrm{~Hz}$ & $\pm 0.2 \%$ \\
\hline
\end{tabular}

In the first part, the R134a, R152a and R444A were tested without IHX. In the second part of the experimental study, the IHX was activated, and the experiments were conducted with the refrigerant R444A.

\section{RESULTS AND DISCUSSION}

Due to the increase in subcooling degree, cooling capacity was improved for R444A with the use of IHX as seen in Fig. 2. R444A had provided higher cooling capacity after IHX was activated. Furthermore, R444A showed similar cooling capacity compared to the R134a.



Fig. 2. P-h diagram of the system with all refrigerants

The performance of the AAC system was analysed with R152a and R444A comparatively under different compressor speeds as an alternative to R134a. Fig. 3 demonstrates the change in the $\dot{Q}_{\text {evap }}$ versus compressor speed for each refrigerant. Clearly, the cooling capacity for R152a was the highest, and followed by R134a, R444A.

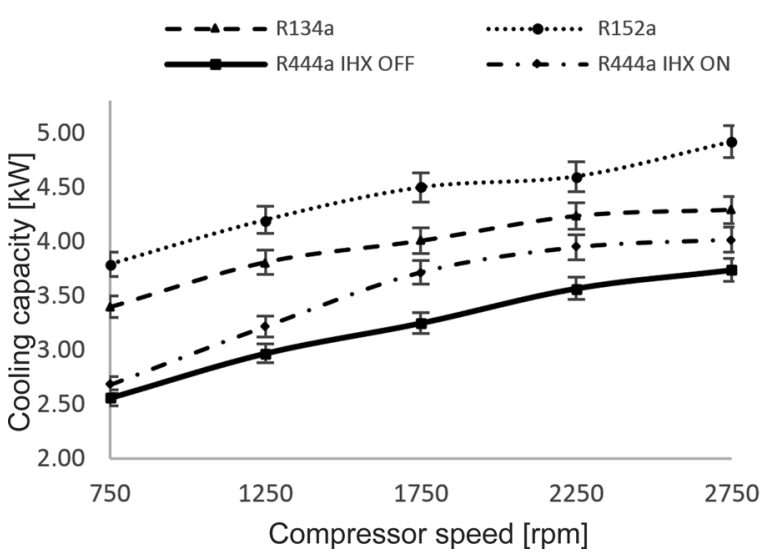

Fig. 3. Variance of the cooling capacity versus compressor speed

Fig. 4 presents the variations of COP according to compressor speed for each refrigerant. It was obvious from Fig. 4; the COP decreases by the rise of the compressor speeds. When the compressor speeds increased, the evaporator pressure dropped and condenser pressure increased, so that mass flow rate was increased, as well.

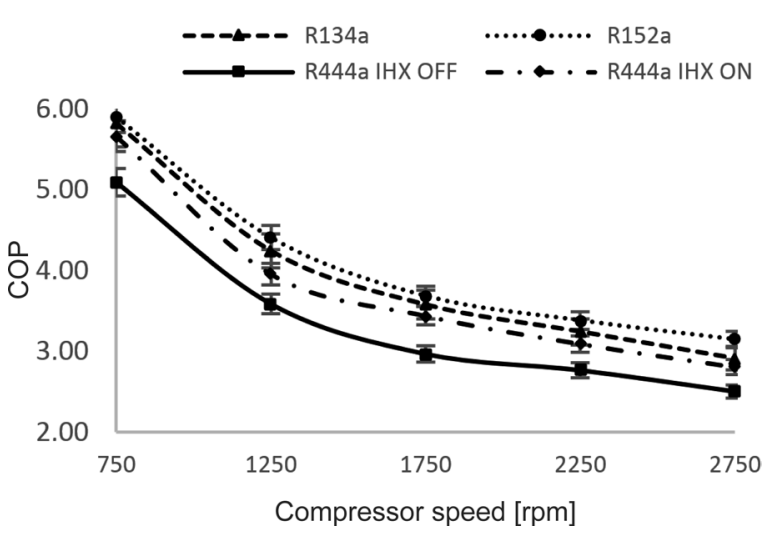

Fig. 4. Variance of the COP versus compressor speed

The highest COP was observed when the system was working with R152a, and it was followed by $\mathrm{R} 134 \mathrm{a}$ and R444A. The R444A has lower $\dot{Q}_{\text {evap }}$ than that of R134a; this led to lower COP. Additionally, due to the amount of subcooling, the enthalpy difference in the evaporator inlet and outlet was increased. The COP of R444A increased with the IHX due to subcooling.

The influence of compressor speed on the $\dot{E} x_{\mathrm{d}}$ for each refrigerant can be seen in Fig. 5. The highest exergy destruction was observed while using the $\mathrm{R} 152 \mathrm{a}$ in the system. The increase in the compressor 
speed increases the mass flow rate, and this lead an increment in exergy destruction rate within the system components.

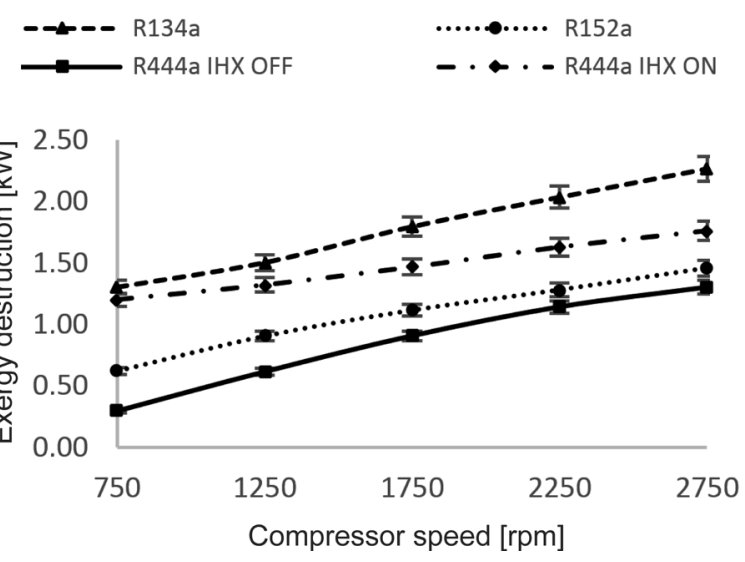

Fig. 5. Variance of the $\dot{E} x_{\mathrm{d}}$ versus compressor speed

Additionally, the condenser pressure and the condensation temperature increased with increasing compressor speeds, while the evaporator pressure and temperature decreased. This was caused an increase in the temperature difference between the refrigerant and air passing through the evaporator and the condenser. Therefore, the exergy destruction was increased for these two components. As a result, the total $\dot{E} x_{\mathrm{d}}$ in the system was increased with the increasing compressor speeds for all refrigerants. On the other hand, R444A had minimum $\dot{E} x_{\mathrm{d}}$ rate due to the lower mass flow rate at all compressor speeds when the IHX was turned off. Furthermore, R444A had higher $\dot{E} x_{\mathrm{d}}$ rate compared to R152a with the use of IHX.

The exergy destruction of the system components at $1750 \mathrm{rpm}$ can be seen in Fig. 6. It was found that the highest $\dot{E} x_{\mathrm{d}}$ within the components belongs to the condenser. When the IHX activated, the $\dot{E} x_{\mathrm{d}}$ in the compressor was increased (Fig. 6). Besides that, adding an IHX to the system caused to a certain amount of exergy destruction. Therefore, the amount of exergy destruction was increased by activating the IHX. $\dot{E} x_{\mathrm{d}}$ of the condenser, evaporator and TXV were reduced when the IHX was activated. However, the $\dot{E} x_{\mathrm{d}}$ rate of the compressor was decreased when the IHX was activated. With the activation of IHX, the increase in superheat at the compressor inlet was considered to be effective at the elimination of the $\dot{E} x_{\mathrm{d}}$ in the compressor.

Figs. 7 and 8 demonstrates the exergy efficiency and variance of exergetic COP as a function of compressor speed, respectively.
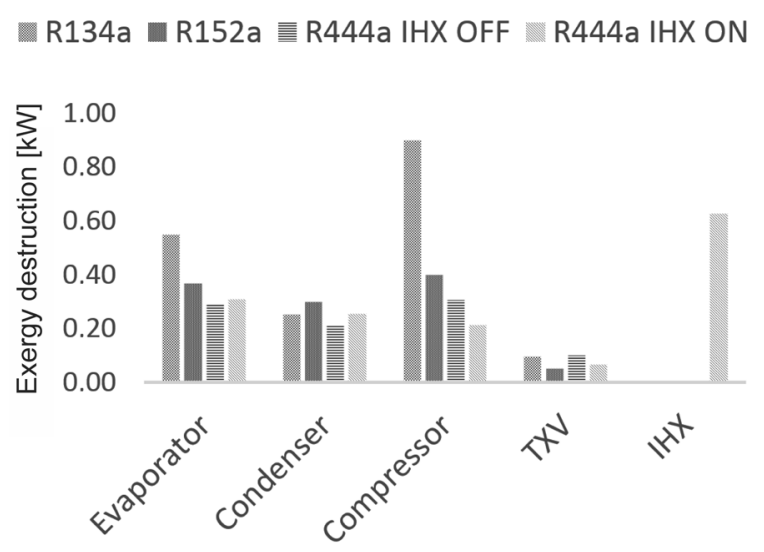

Fig. 6. Variance of the $\dot{E} x_{\mathrm{d}}$ of the system components

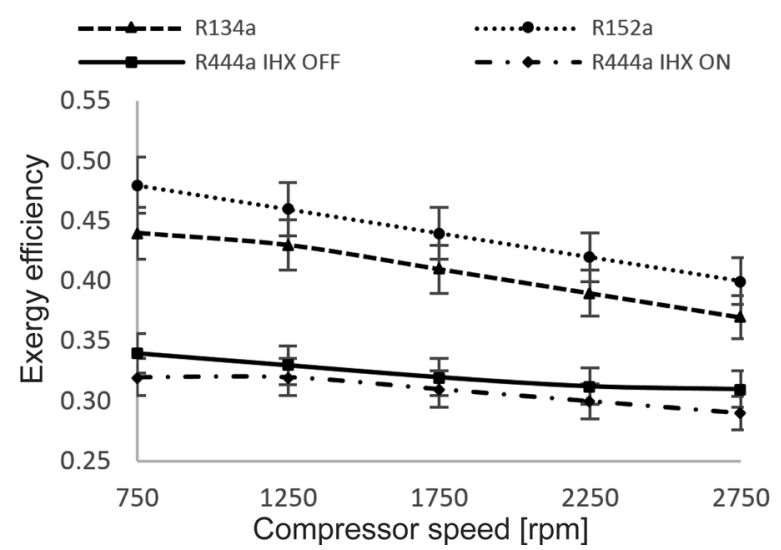

Fig. 7. Variance of the exergy efficiency versus compressor speed

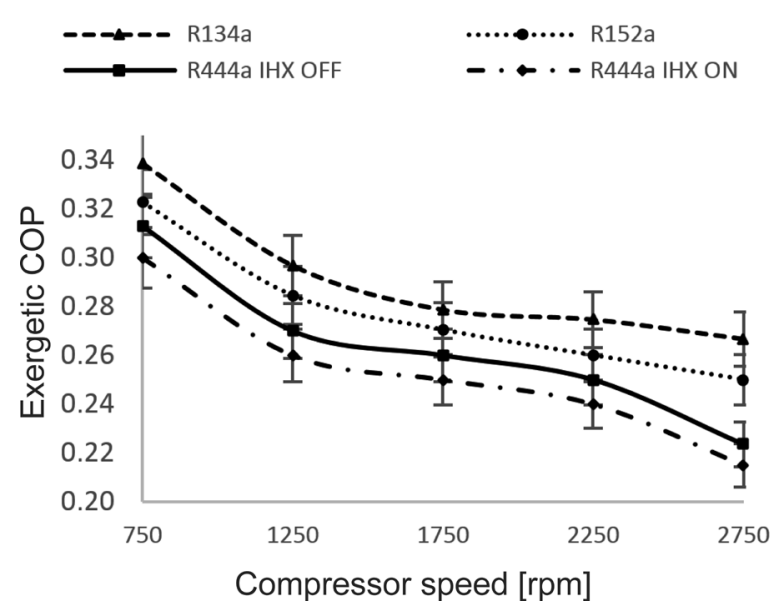

Fig. 8. Variance of Exergetic COP versus compressor speed

According to the Fig. 8, as the heat transfer rate between refrigerant and air at the condenser and evaporator increases with compressor speed, both the exergy efficiency and exergetic COP decreases. At all compressor speeds, R152a has the highest exergy efficiency and R444A (with IHX) has the lowest 
exergy efficiency (Fig. 7). On the other hand, exergetic COP of the R134a was the highest while R444A (with IHX) had already the lowest exergetic COP (Fig. 8).

\section{CONCLUSIONS}

The use of low GWP valued refrigerants were tested in order to find an alternative refrigerant to R134a. For this aim, an AAC system was set up to perform the experimental study. The R152a and R444A were tested against an alternative to the R134a. An IHX was added to provide increased performance during the system operation, and the experiments were repeated with IHX for the refrigerant R444A. $\dot{Q}_{\text {evap }}$, $\dot{W}_{\text {comp }}, \mathrm{COP}$, and total $\dot{E} x_{\mathrm{d}}$ were determined as performance parameters, and the results were obtained.

The highest cooling capacity was obtained when the R152a is charged to the system compared to the other refrigerants, and it was followed by R134a and R444A respectively. The obtained cooling capacity with R444A is lower than R152a and R134a, however it was relatively increased when the IHX was activated. On the other hand, the highest COP value was obtained with R152a for all compressor speeds. Then, it was followed by R134a, R444A, respectively. The COP of R444A were increased when the IHX was activated. Furthermore, the minimum exergy destruction rates occurred with R444A (when IHX was off) for all compressor speeds. Exergy destruction of R152a was found to be slightly higher than R444A and it was followed by R444A with IHX. Exergy destruction rate of the system with R134a was the highest. It was found that the exergy destruction was increased with the activation of the IHX as well as with the increased compressor speeds.

Consequently, it has become imperative to find an alternative refrigerant to R134a due to European Union restrictions. The results of this study may be used for further investigations for the economic evaluations.

\section{ACKNOWLEDGEMENTS}

The authors would like to thank the Scientific and Technological Research Council of Turkey (TÜBITAK) supporting this study through a Research Project No 216M437.

\section{NOMENCLATURE}

$\begin{array}{ll}\dot{Q} & \text { heat transfer, }[\mathrm{kW}] \\ \dot{W} & \text { work, }[\mathrm{kW}]\end{array}$

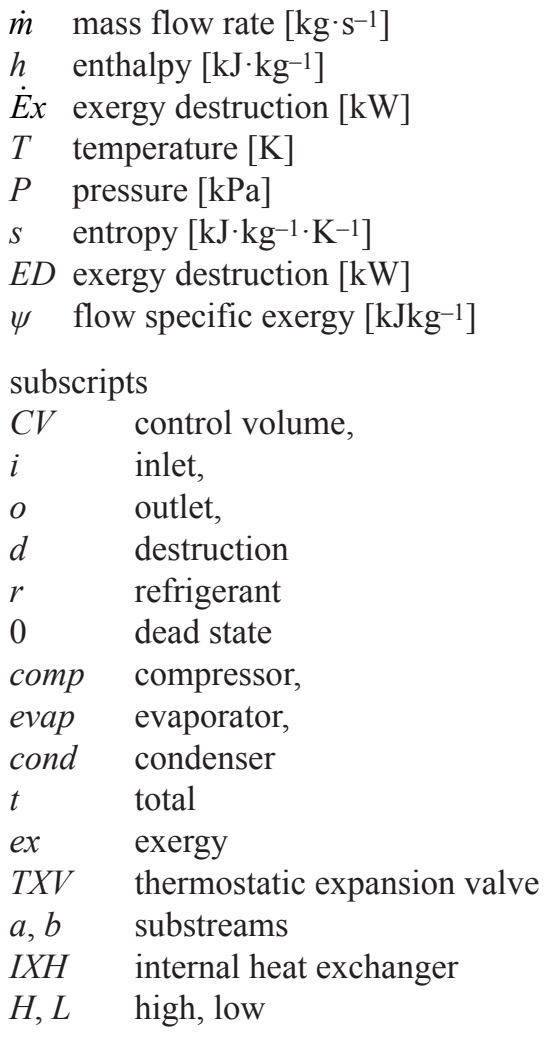

\section{REFERENCES}

[1] Directive 2006/40/EC of the European Parliament and of the Council of 17 may 2006 relating to emissions from air conditioning systems in motor vehicles and amending council directive 70/156/EC. Official Journal of European Union 161, 2006, 1e11, D0I:10.1007/978-1-137-54482-7_31.

[2] Regulation (EU) No 517/2014 of the European Parliament and the Council of 16 April 2014 on Fluorinated Greenhouse Gases and Repealing Regulation (EC) No 842/2006 (2014). Official Journal of the European Union, Brussels.

[3] Lemmon, E.W., Huber, M.L., McLinden, M.O. (2014). REFPROP, NIST Standard Reference Database 23, v.9.1. National Institute of Standards. Gaithersburg.

[4] Myhre, G., Shindell, D., Breon, F.M., Collins, W., Fuglestvedt, J., Huang, J., et al. (2013). Stocker, T.F., Qin, D., Plattner, G.K., Tignor, M., Allen, S.K., Boschung, J., et al. (eds.). IPCC 2013 Assessment Report 5th Climate Change: The Physical Science Basis, the Intergovernmental Panel on Climate Change, (Chapter 8 anthropogenic and natural radiative forcing). Cambridge University Press, Cambridge, NewYork D0l:10.1017/cbo9781107415324.019.

[5] Mota-Babiloni, A., Makhnatch, P., Khodabandeh, R. (2017). Recent investigations in HFCs substitution with lower GWP synthetic alternatives: Focus on energetic performance and environmental impact. International Journal of Refrigeration, vol. 82, p. 288-301, D0l:10.1016/j.jjrefrig.2017.06.026.

[6] Leighton, D. (2012). Modeling of household refrigerator performance with low global warming potential alternative refrigerants. ASHRAE Transactions, vol. 118, p. 658-665. 
[7] Janković, Z., Sieres-Atienza, J., Martínez-Suárez, J.A. (2015). Thermodynamic and heat transfer analyses for R1234yf and $\mathrm{R} 1234 z e(E)$ as drop-in replacements for R134a in a small power refrigerating system. Applied Thermal Engineering, vol. 80, p. 42-54, D0l:10.1016/j.applthermaleng.2015.01.041.

[8] Direk, M., Soylu, E. (2018). The Effect of internal heat exchanger using $\mathrm{R} 1234 z e(E)$ as an alternative refrigerant in a mobile air-conditioning system. Strojniški vestnik - Journal of Mechanical Engineering, vol. 64, no. 2, p. 114-120, DOI:10.5545/sv-jme.2017.5093.

[9] Cheng, Z., Wang, B., Shi, W., Li, X. (2017). Numerical research on R32/R1234ze(E) air source heat pump under variable mass concentration. International Journal of Refrigeration, vol. 82, p. 1-10, D0l:10.1016/j.ijrefrig.2017.06.014.

[10] Devecioğlu, A. G., Oruç, V. (2017). An analysis on the comparison of low-GWP refrigerants to alternatively use in mobile air-conditioning systems. Thermal Science and Engineering Progress, vol. 1, p. 1-5, D0l:10.1016/j. tsep.2017.02.002.

[11] Lee H., Hwang Y., Song I., Jang K. (2015). Transient thermal model of passenger car's cabin and implementation to saturation cycle with alternative working fluids. Energy, vol. 90, p. 1859-1868, D0l:10.1016/j.energy.2015.07.016.

[12] Meng, Z., Zhang, H., Qiu, J., Lei, M. (2016). Theoretical analysis of R1234ze (E), R152a, and R1234ze (E)/R152a mixtures as replacements of $\mathrm{R} 134 \mathrm{a}$ in vapor compression system. Advances in Mechanical Engineering, vol. 8, no. 11, p. 1-10, DOI:10.1177/1687814016676945.

[13] Li, G., Eisele, M., Lee, H., Hwang, Y., Radermacher, R. (2014). Experimental investigation of energy and exergy performance of secondary loop automotive air-conditioning systems using low-GWP (global warming potential) refrigerants. Energy, vol. 68, p. 819-831, D0I:10.1016/j.energy.2014.01.018.

[14] Ghodbane, M. (1999). An investigation of R152a and hydrocarbon refrigerants in mobile air conditioning. $S A E$
Transactions, vol. 108, p. 1658-1673, Dol:10.4271/1999-010874.

[15] Scherer, L.P., Ghodbane, M., Baker, J.A., Kadle, P.S. (2003). On-vehicle performance comparison of an R-152a and R-134a heat pump system. SAE Technical Paper, no. 2003-01-0733, DOI:10.4271/2003-01-0733.

[16] Lee, D. (2015). Experimental study on the heat pump system using R134a refrigerant for zero-emission vehicles. International Journal of Automotive Technology, vol. 16, no. 6, p. 923-928, DOl:10.1007/s12239-015-0094-2.

[17] Klein, S.A., Reindl, D.T., Brownell, K. (2000). Refrigeration system performance using liquid-suction heat exchangers. International Journal of Refrigeration, vol. 23, no. 8, p. 588596, D0I:10.1016/S0140-7007(00)00008-6.

[18] Molés, F., Navarro-Esbrí, J., Peris, B., Mota-Babiloni, A., Barragán-Cervera, Á. (2014). Theoretical energy performance evaluation of different single stage vapour compression refrigeration configurations using R1234yf and R1234ze(E) as working fluids. International Journal of Refrigeration, vol. 44, p. 141-150, D0l:10.1016/j.jjrefrig.2014.04.025.

[19] Mota-Babiloni, A., Navarro-Esbrí, J., Juan Manuel MendozaMiranda, Bernardo Peris, (2017). Experimental evaluation of system modifications to increase R1234ze(E) cooling capacity. Applied Thermal Engineering, vol. 111, p. 786-792, DOI:10.1016/j.applthermaleng.2016.09.175.

[20] Mota-Babiloni A., Navarro-Esbrí J., Barragán-Cervera Á., Molés F., Peris B. (2015). Experimental study of an R1234ze(E)/ R134a mixture (R450A) as R134a replacement. International Journal of Refrigeration, vol. 51, p. 52-58, D0l:10.1016/j. ijrefrig.2014.12.010.

[21] Dincer, I., and Rosen, M. A., (2015). Chapter 4 - Heat Pump Systems. Exergy Analysis of Heating, Refrigerating and Air Conditioning. Elsevier, Boston, D0l:10.1016/B978-0-12417203-6.00004-1. 